Received: 17 June 2021 :: Accepted: 30 June 2021 :: Published: 30 June 2021

\title{
PENGARUH LATIHAN AEROBIK TERHADAP KUALITAS HIDUP PASIEN PENYAKIT PARU OBSTRUKTIF KRONIK
}

\author{
Anita Sri Gandaria Purba ${ }^{1}$, Dian Anggri Yanti ${ }^{1}$, Nur Hamida Pohan ${ }^{1}$ \\ ${ }^{1}$ Program Studi Keperawatan, Institut Kesehatan Medistra Lubuk Pakam \\ JIn. Sudirman No.38 Lubuk Pakam, Kabupaten Deli Serdang, \\ Sumatera Utara - Indonesia \\ *email korespondensi author: anitapurba85@gmail.com
}

DOI $10.35451 /$ jpk.v1i1.758

\begin{abstract}
Abstrak
Penyakit paru obstruktif kronik (PPOK) adalah peradangan kronis pada paru-paru yang menyebabkan terhambatnya aliran udara melalui saluran udara. PPOK adalah penyakit progresif dan PPOK (penyakit paru obstruktif kronik) berarti semakin memburuk dari waktu ke waktu. Pada penderita PPOK, pernapasan tidak normal dan kondisi yang terjadi dengan PPOK dapat menyebabkan dispnea. Ketika gejala PPOK (Penyakit Paru Obstruktif Kronik) berkembang selama bertahun-tahun, gejala PPOK mempengaruhi tingkat aktivitas dan kualitas hidup. Gejala PPOK bisa tiba-tiba memburuk. Penderita PPOK mengalami sesak napas berupa sesak napas, batuk kronis, produksi sputum kronis, dan aktivitas terbatas. Latihan aerobik pada pasien PPOK bertujuan untuk mengurangi gejala, meningkatkan kualitas hidup, dan meningkatkan aktivitas seharihari. Penelitian ini bertujuan untuk mengetahui pengaruh senam aerobik terhadap kualitas hidup pasien PPOK.Penelitian ini merupakan penelitian kuantitatif melalui sosialisasi dan penyuluhan dengan menggunakan metode sampling sebanyak 44 responden. Data dikumpulkan dengan menggunakan kuesioner tentang kualitas hidup pasien PPOK. Hasil uji-t yang didukung menunjukkan nilai signifikan. 0,000 berarti signifikan. 0,05 menunjukkan bahwa senam aerobik secara umum berpengaruh terhadap kualitas hidup pasien PPOK. Pasien PPOK yang akan melakukan latihan aerobik secara teratur dapat mengurangi gejala PPOK, terutama sesak napas, dengan meningkatkan asupan cairan untuk memenuhi kebutuhan jaringannya. Jenis olahraga yang dianjurkan bagi penderita PPOK adalah olahraga aerobik, yang bertujuan untuk meningkatkan kesehatan dan kebugaran, terutama meningkatkan efisiensi dan fungsi metabolisme tubuh. Latihan aerobik seperti lari, berenang, latihan kelompok, dan bersepeda cocok untuk penderita PPOK karena mereka menggunakan semua otot utama, pernapasan, dan jantung mereka.
\end{abstract}

Kata kunci: Latihan Aerobik, Kualitas Hidup,PPOK

\begin{abstract}
Chronic obstructive pulmonary disease (COPD) is a chronic inflammation of the lungs that causes obstruction of airflow through the airways. COPD is a progressive disease and COPD (chronic obstructive pulmonary disease) means it gets worse over time. In people with COPD, abnormal breathing and conditions that occur with COPD can cause dyspnea. As COPD (Chronic Obstructive Pulmonary Disease) symptoms develop over
\end{abstract}


Received: 17 June 2021 :: Accepted: 30 June 2021 :: Published: 30 June 2021

the years, COPD symptoms affect activity levels and quality of life. COPD symptoms can suddenly get worse. COPD sufferers experience shortness of breath in the form of shortness of breath, chronic cough, chronic sputum production, and limited activity. Aerobic exercise in COPD patients aims to reduce symptoms, improve quality of life, and improve daily activities. This study aims to determine the effect of aerobic exercise on the quality of life of COPD patients. This research is a quantitative study through socialization and counseling using a sampling method of 44 respondents. Data were collected using a questionnaire about the quality of life of COPD patients. The supported t-test results show significant values. 0.000 means significant. 0.05 indicates that aerobic exercise in general affects the quality of life of COPD patients. COPD patients who will engage in regular aerobic exercise can reduce COPD symptoms, especially shortness of breath, by increasing fluid intake to meet the needs of their tissues. The type of exercise that is recommended for people with COPD is aerobic exercise, which aims to improve health and fitness, especially increasing the efficiency and function of the body's metabolism. Aerobic exercises such as running, swimming, group exercise, and cycling are suitable for people with COPD because they use all of their major, respiratory, and heart muscles.

Keywords: Aerobic Exercise, Quality Of Life, COPD

\section{Pendahuluan}

Kesehatan adalah dambaan setiap manusia di seluruh dunia. Namun, seiring bertambahnya waktu dan populasi, begitu pula jumlah orang yang akan terinfeksi penyakit ini. PPOK (Penyakit Paru Obstruktif Kronik) merupakan kondisi yang paling banyak diderita oleh masyarakat umum (Potter \& Perry, 2012). PPOK, atau penyakit paru obstruktif kronik, adalah kondisi pernapasan yang prevalensi, morbiditas, dan mortalitasnya meningkat dari tahun ke tahun.

Menurut Organisasi Kesehatan Dunia (WHO), PPOK adalah penyebab kematian terbesar ketiga di dunia pada tahun 2014, sedangkan pada tahun 2015 telah menempati urutan ke-2 sebagai penyakit yang menyebabkan kematian (Petty, 2016).

PPOK adalah penyebab kematian keempat di Amerika Serikat. Angka kematian akibat PPOK adalah 119 per 2.000 penduduk. PPOK merupakan penyebab kematian ketiga pada pria berusia 557 tahun dan penyebab kematian keempat pada wanita pada kelompok usia yang sama. Dari tahun 1990 hingga 2012, angka kematian akibat PPOK meningkat sebesar $28,2 \%$ pada wanita dibandingkan dengan $13 \%$ pada pria (Bauldoff, 2011 ). PPOK merupakan masalah kesehatan masyarakat utama di Inggris dengan 26.000 kematian setiap tahunnya. Prevalensinya adalah 600.000 orang. 8 Angka ini lebih tinggi di negara maju, daerah perkotaan, kelas menengah ke bawah dan orang tua. (WHO, 2014)

CPOD Roundtable Asia Pacific
memperkirakan 56,6 juta orang di negara-negara Asia Pasifik menderita PPOK sedang hingga berat, dengan tingkat prevalensi 6,3 persen (Davey,2014). Angka kejadian PPOK di Indonesia diperkirakan mencapai 4,8 juta penderita dengan prevalensi $5,6 \%$. Pada tahun 2010, PPOK menduduki peringkat ke-8 dari 10 besar penyakit untuk pasien rawat jalan di BP4 Sumut sebanyak 1401 kasus, dan peringkat ke-5 untuk pasien rawat inap dengan 51 kasus, sedangkan pada tahun 2015 pasien rawat jalan peringkat ke- 6 dengan 646 kasus dan pasien rawat inap peringkat ke-3 dengan 647 kasus dengan 92 pasien (Dinkes Sumut, 2015). 
Received: 17 June 2021 :: Accepted: 30 June 2021 :: Published: 30 June 2021

Gejala klinis PPOK antara lain batuk, produksi sputum, sesak nafas dan keterbatasan aktivitas. Ketidakmampuan beraktivitas pada pasien PPOK terjadi bukan hanya akibat dari adanya kelainan obstruksi saluran nafas pada parunya saja tetapi juga akibat pengaruh beberapa faktor,salah satunya adalah penurunan fungsi otot skeletal.Adanya disfungsi otot skeletal dapat menyebabkan penurunan kualitas hidup penderita karena akan membatasi kapasitas latihan dari pasien PPOK. Penurunan aktivitas pada kehidupan sehari-hari akibat sesak nafas yang dialami pasien PPOK akan mengakibatkan makin memperburuk kondisi tubuhnya (Agustin, 2015). Faktor patofisiologi yang diperkirakan berkontribusi dalam kualitas dan intensitas sesak nafas saat melakukan aktivitas pada PPOK antara lain kemampuan mekanis (elastisitas dan reaktif) dari otot-otot inspirasi, meningkatnya mekanis (volume) restriksi selama beraktivitas, lemahnya fungsi otot-otot inspirasi, meningkatnya kebutuhan ventilasi relatif terhadap kemampuannya, gangguan pertukaran gas, kompresi jalan nafas dinamis dan factor kardiovaskuler. Akibatnya, pasien PPOK cenderung menghindari latihan fisik, mengakibatkan imobilisasi, penurunan hubungan pasien dengan lingkungan dan situasi sosial, dan penurunan kualitas hidup.

Kualitas hidup pasien PPOK sangat penting karena terkait dengan sesak napas, yang membuat pasien sulit untuk melakukan aktivitas fisik (Agustin, 2015). Latihan fisik adalah modalitas yang penting dalam pengobatan pasien PPOK. Latihan fisik dapat memperbaiki daya tahan fisik, kapasitas aerobik, dan kapasitas oksidatif otot skeletal. Akan tetapi, pada beberapa penderita PPOK berat mungkin mendapat kesulitan dalam melaksanakan latihan fisik (khususnya latihan dengan intensitas tinggi) akibat gangguan sistem kardiovaskular. Keterbatasan dalam latihan fisik sering menyebabkan perburukan secara perlahan-Iahan terhadap kapasitas latihan dan kekuatan otot (Waspodo, 2014).

Jenis olahraga yang dianjurkan untuk pasien PPOK adalah aerobik, terutama untuk meningkatkan fungsi dan efisiensi metabolisme tubuh. Latihan aerobik seperti lari, berenang, latihan kelompok, dan bersepeda cocok untuk pasien PPOK karena menggunakan semua otot utama, pernapasan, dan jantung. Misalnya, dalam latihan aerobik, menyesuaikan langkah-langkah tindakan untuk memenuhi dan melakukan kriteria CRIPE (terus menerus, berirama, intermiten), bertahap, terus menerus) dalam berbagai gerakan, termasuk gerak kaki dasar dan berjalan (Agustin, 2015).

\section{Metode}

Kegiatan Pengabdian Kepada Masyarakat (PKM) ini menggunakan metode berupa sosialisasi penyuluhan kesehatan terkait dengan pemberian latihan aerobic pada pasien PPOK.Dengan tujuan meningkatkan kualitas hidup pada pasien PPOK.Kegiatan PKM ini dilakukan di Rumah Sakit Umum Daerah Deli Serdang. Sasaran pada kegiatan PKM ini adalah pasien PPOK Yang mengalami gangguan aktivitas yang berjumlah 44 orang.

\section{Hasil dan Pembahasan}

\subsection{Hasil}

Tabel 1 Rata rata kualitas hidup pasien sebelum latihan aerobik

Variabel Kualitas hidup

Frekuensi Persentase

\begin{tabular}{lll} 
Baik & 10 & $22.7 \%$ \\
Kurang & 24 & $54.6 \%$ \\
Buruk & 10 & $22.7 \%$ \\
\hline Total & $\mathbf{4 4}$ & $\mathbf{1 0 0} \%$
\end{tabular}

Berdasarkan tabel distribusi frekuensi diatas menunjukan bahwa mayoritas kualitas hidup pasien 
Received: 17 June 2021 :: Accepted: 30 June 2021 :: Published: 30 June 2021

penyakit paru obstruktif kronik sebelum dilakukan latihan aerobik paling banyak kurang baik 24 responden $(54.5 \%)$, kualitas hidup pasien penyakit paru obstruktif kronik yang buruk 10 responden (22.7\%), dan kualitas hidup pasien penyakit paru obstruktif kronik baik 10 responden $(22.7 \%)$.

Tabel 2 Rata rata kualitas hidup pasien sesudah latihan aerobik

$$
\text { Variabel Kualitas hidup }
$$

Frekuensi Persentase

\begin{tabular}{lcc} 
Baik & 21 & $47.4 \%$ \\
Kurang & 18 & $40.9 \%$ \\
Buruk & 5 & $11.7 \%$ \\
\hline Total & $\mathbf{4 4}$ & $\mathbf{1 0 0} \%$
\end{tabular}

Berdasarkan tabel distribusi frekuensi diatas menunjukan bahwa mayoritas kualitas hidup pasien penyakit paru obstruktif kronik setelah dilakukan latihan aerobik paling banyak baik 21 responden $(47.4 \%)$, kualitas hidup pasien penyakit paru obstruktif kronik yang kurang baik 18 responden (40.9\%), dan kualitas hidup pasien penyakit paru obstruktif kronik buruk 5 responden (11.4\%)Berdasarkan hasil uji statistic Berdasarkan hasil uji statistik dengan menggunakan $u \mathrm{ji}$ paired $t$ test menunjukan bahwa rerata kualitas hidup pasien penyakit paru obstruktif.

\subsection{Sosialisasi Penyuluhan Kesehatan pemberian Latihan Aerobik pada pasien PPOK}

Sosialisasi yang diberikan kepada masyarakat pada kegiatan PKM ini meliputi penyuluhan kesehatan tentang pemberian latihan aerobic dengan latihan yang diberikan selama 2 kali sehari pada pagi hari dan sore hari dengan durasi 30 menit setiap latihan, pelaksanaan ini dilakukan selama 3 minggu.

\section{Kesimpulan}

Pasien PPOK yang mengalami gangguan pada kualitas hidup sebelum perlakuan yang kualitas hidup nya buruk 10 orang dan setelah diberikan perlakuan menjadi 5 orang. Penerapan untuk latihan aerobic pada pasien PPOK terus dilakukan untuk terapi non farmakologi yang dapat dilakukan oleh masyarakat.

\section{UcapanTerimaKasih}

Ucapan terimakasih yang sebesar besarnya kepada Institut Kesehatan Medistra Lubuk Pakam, Lembaga Penelitian dan Pengabdian Kepada Masyarakat Institut Kesehatan Medistra Lubuk Pakam, Direktur Rumah Sakit Umum Daerah Deli Serdang, dan semua pihak yang telah mendukung kegiatan PKM ini yang tidak dapat saya sebut kan satu per satu.

\section{DaftarPustaka}

Alimul, A. Aziz. 2016. Pengantar Kebutuhan Dasar Manusia. Jakarta: Salemba Medika

American Diabetes Association.(2015). Diabetes type 2 . from http://www.diabetes.org

Borrott, N. \& Bush, R. (2018). Measuring Quality Of Life Among Those With COPD In Primary Care.

Boyd, L. (2011). Physical, Mental \& Social Effects of Diabetes.

Giriwoyo, H. Y. S. Santosa.(2017). Ilmu Faal Olahraga, Fungsi Tubuh Manusia pada Olahraga. Bandung: Rosdakarya.

Harisson. (2015). Prinsip-prinsip Ilmu Penyakit Dalam. Editor edisi bahasa Indonesia. Jakarta: EGC Heathplus.

s_and_Conditions1/Diabetes.asp

$x$ Indriyanti RS. (2013). Pemeriksaan Laboratorium untuk Diagnosis dan Pemantauan Diabetes Mellitus. Forum Diagnosticum: 


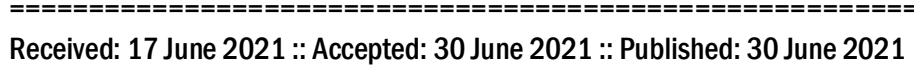
Laboratorium Klinik Prodia. International Diabetes Federation. (2017). Diabetes Atlas: Impact On The Individual.

Sardar, Mohammad Ali. dkk. (2014).The Effects of Aerobic Exercise Training on Psychosocial Aspects of Men with COPD. Health Science : Canadian Center if Sciense and Education

Slamet, Suyono.(2016). Modifikasi Gaya Hidup Sehat Cegah Timbulnya Penyakit. http://www.swaranet.com

Smeltzer. (2018). Buku Ajar Keperawatan Medikal Bedah. Volume I Edisi VIII. Jakarta : EGC

Sudoyo, A. W. Et al (eds). (2018). Buku Ajar Ilmu Penyakit Dalam. Jilid III. Edisi V. Jakarta: Pusat Penerbit Illmu Penyakit Dalam.

Sugiyono. (2018). Statistik Untuk Penelitian. Edisi Satu. Bandung: CV Alfa Beta.

Sutedjo, A.Y. (2012). Buku Saku Mengenal Penyakit Melalui Hasil Pemeriksaan Laboratorium. Yogyakarta : Amara Books.

WHO.(2014). The World Health Organization Quality of Life (WHOqol-Bref) Indonesia Version 